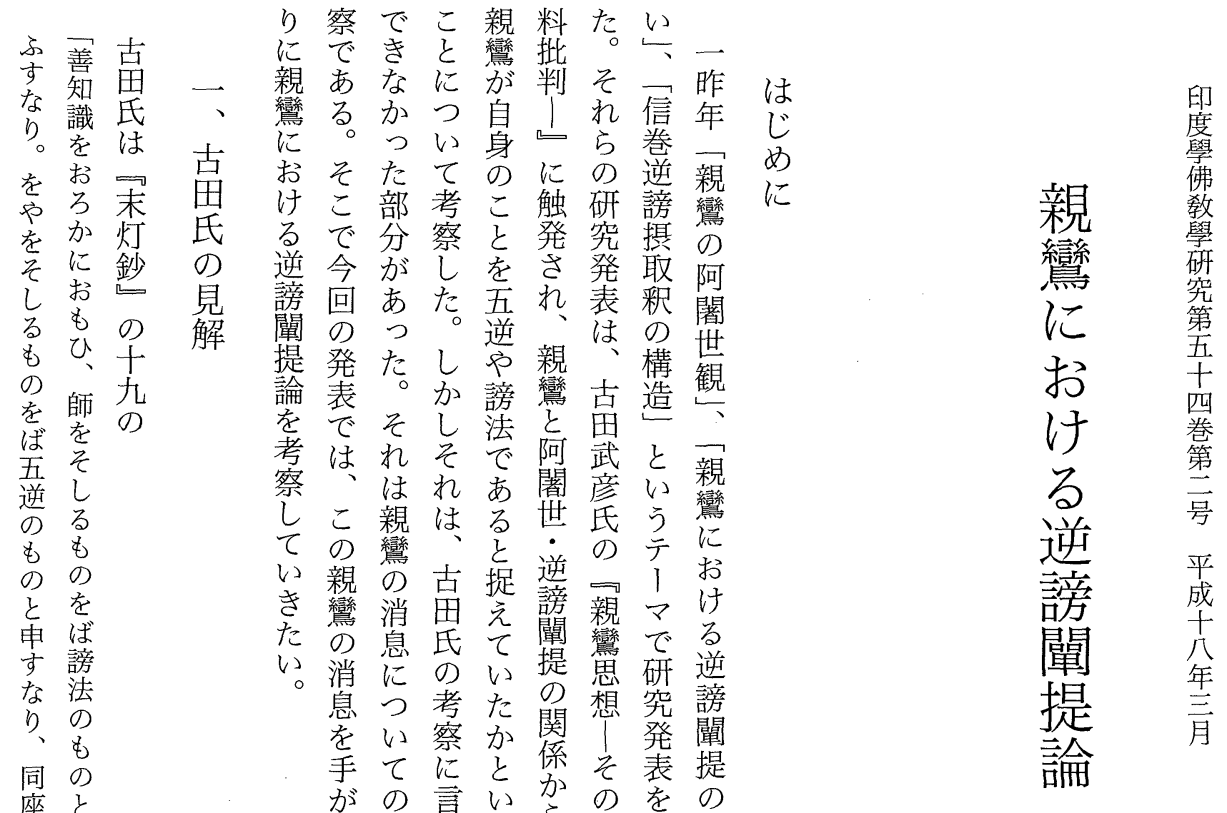

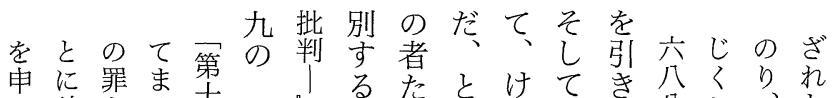

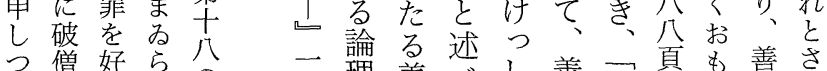

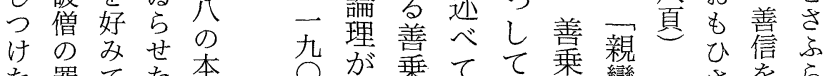

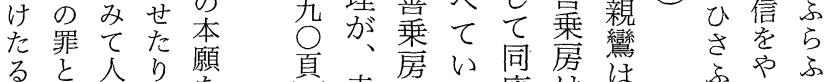
赤側る座注は方方な

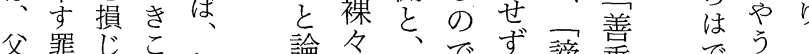

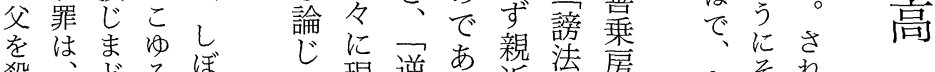

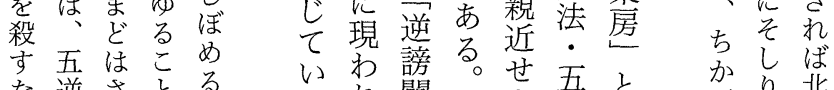

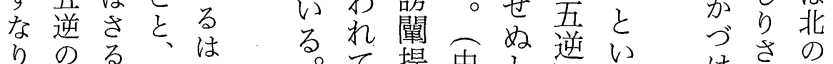

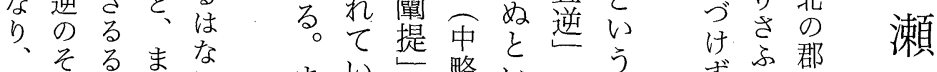

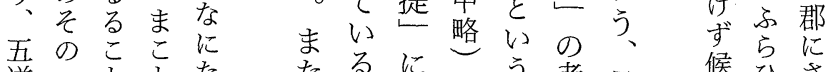

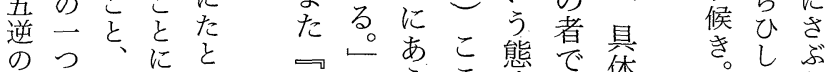

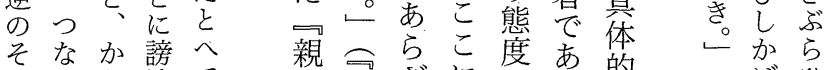

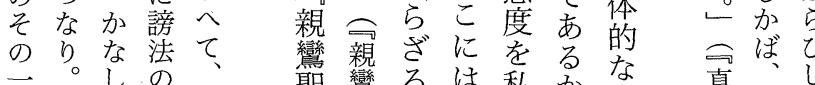

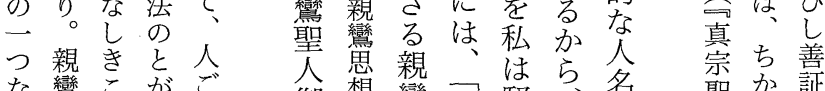

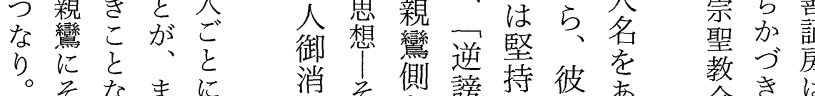

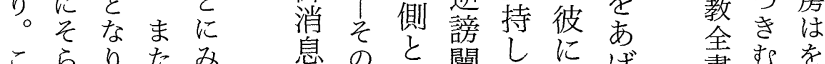

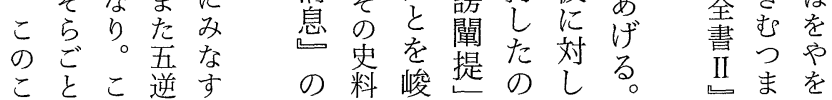


実田

こたゔよ御祭氐 ま

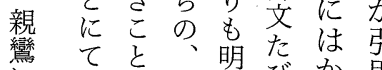

にもにこ法びか用杢

け候てれ御だるし灯末

る ば候に房ます部鈔灯

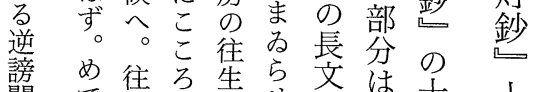

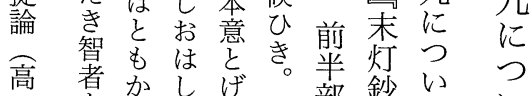

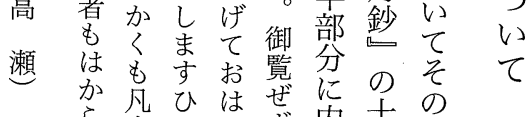

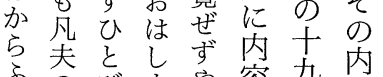

ぶのびまや容九内

べはとし候のの容

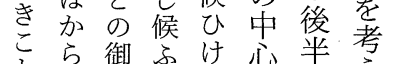

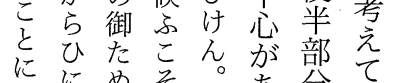

ににめそ。あ分て

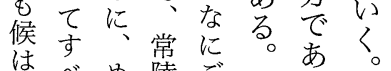

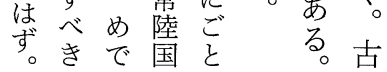

る、思る一らい関抽を 結想拡なごう、係象引土親と

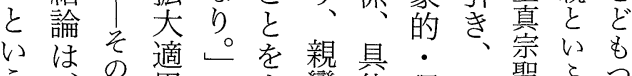
う只用とま鸞体理こ聖ふつ の逆料さいふの的論こ骨こた で謗判あるしう態な的に釉あき

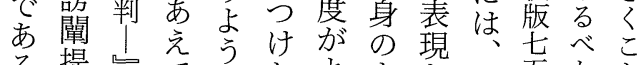

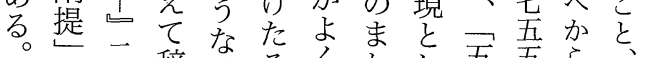

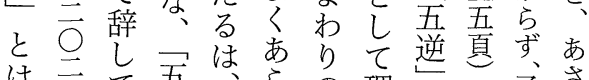
は頁て五品ちす理—文 反とな山逆ちお事解謗拈

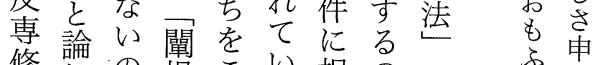
修調の提こい相のの恶 念てが是ろる。当で問充か 仏い注概す、导は題持ぎ 体る慁念なしかせな索をり 制。さのり㔔てくな そそれ、礼指、単きけ のしる。現五、摘現に単にれ もて。実逆親す実経たば

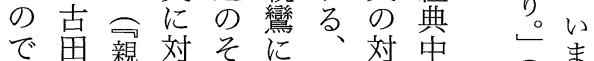

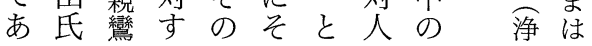

と明ししのしくはお念しはばのもめ悩さ略なますこ大

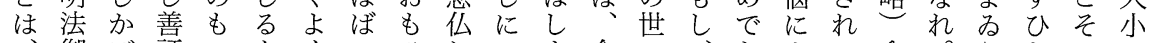

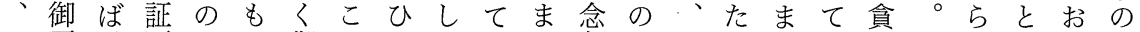
そ房、房との御々かてはさ仏い打きどね欲とせびは聖 ののちは电をこ、へ往順めにとも仏はたのかたとし人 同往か、すばこ世し生次にこはふのささむ煩くまはまだ 朋生づおな謗ろをてねのてこしま御れべ悩はふら、すに にのきやり法えい、が往候ろかじちてくにかこたこも

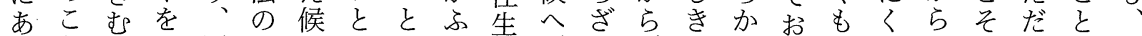

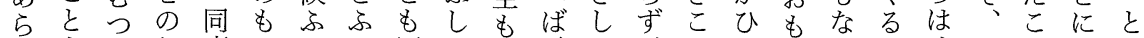

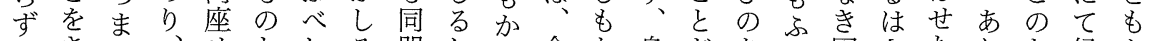
候きじ、せをしる朋した念な身ぞあま因さたりち候か ふきく善ざ申。しににく仏くのももれ呑果れまがかへく

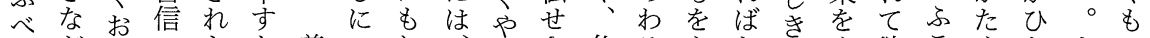
しがも合な善てね、候さ仏ろもとこや欲こくあまは

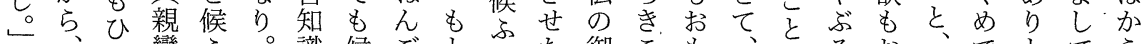

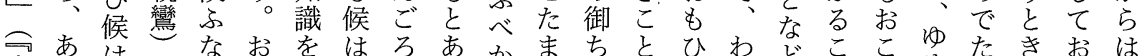

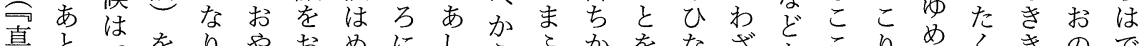

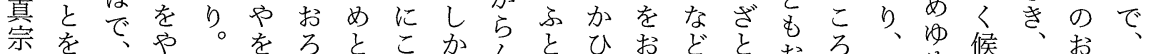

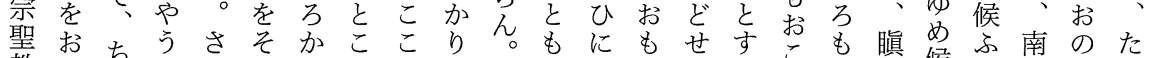

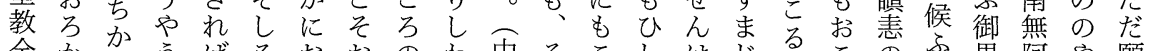

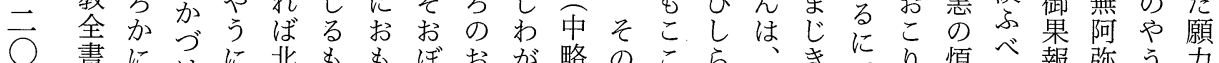

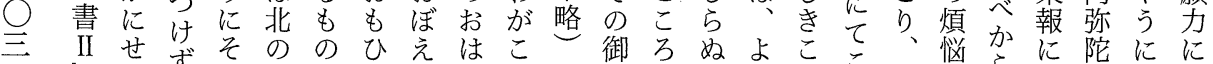

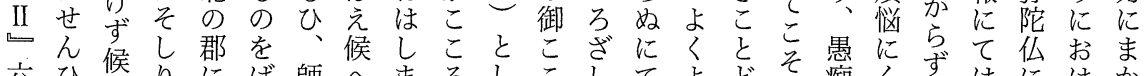

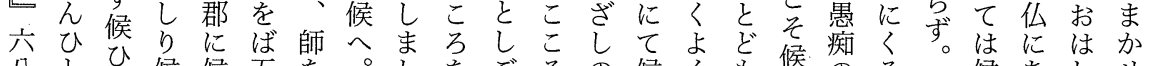
八をひ候候五を。しをごろの候くも候のるる。候あししせ

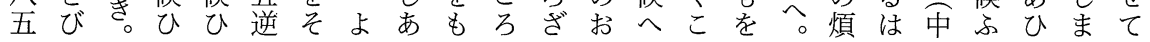


は教すしれか

なえるてるらこ らをもい。手の な正のるそ紙消 いしは。こを息 こく、はでもは と伝往か親ら

でえ生ら鸞つ明 あてはい等て法 りい困を、い房 、た難もまての そ明でつず、死 の 法あて、、後 よ房ろ、はれに うのうしかに起 なことてら対こ もとしはいしう のをてなをてた は軽いら持出異 同んるなつし義 朋じ。いてたに でるつこは返つ はこまとい事い なとりをけとて いは念しな考門 とし仏たい并 いてのりとら達
る同のべふにしよどの候る生こ 朋こかともらくも段ふわにの! にとらもこぬよを落べけつ消六 あをんにこにたた息公 らきしそうてしし明らがて公㝈 ずきとのざ候の、確ず、書は具掠

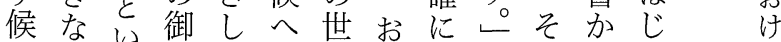
ふがうこのばのも示とのれめ

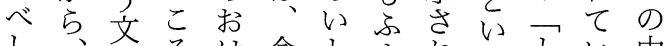

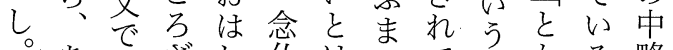
○ああざし仏はじてこかる略 ととるしまにしまいてく いをるにさこかてるがはで

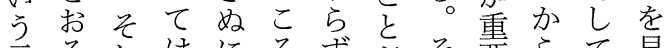

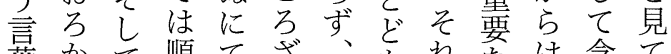
葉かて順てざ、もれなは念て でに最次候し身をはのせ仏み 締せ後のへものもるでた

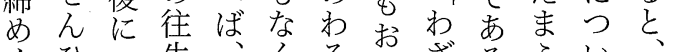

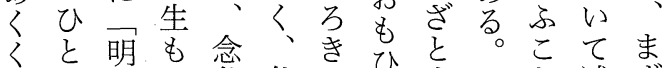

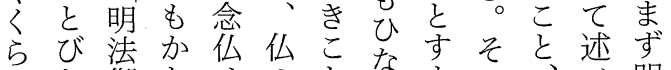
れと御たせのと市のの、べ明 るは房くさ御を劣じこゆら法 の、のやせち拉さとめれ房 でそ往候たかももんこがゆての あの生琼ひひひは次めい往
こるてのい

そここは真。死

でと

く異述しと法。力し起唱

義べては弥でまこえ

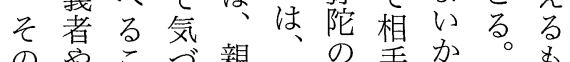

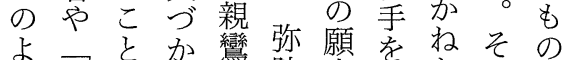

う五々 さ自陀力改なうをを

な逆しれ身のにあいす改

者謗てたが願まますかかれ

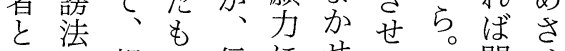

は 法 親の 信にせせ

親が䌌で機よるる

しどがあ の つ よ と

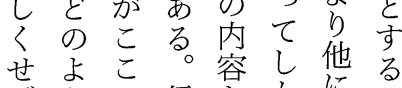

ずうで信と市になる

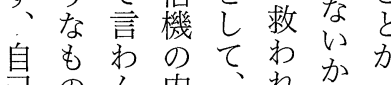

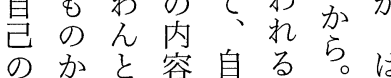

はと立と容自道。

がてつ自注

らういい身な
門 せ

弟 よ

の 5

間と

にす

よ的

りば

大

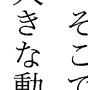

少

5
らいに親でい教いこ房う 1)れうは鸞あこえうとと

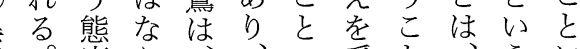

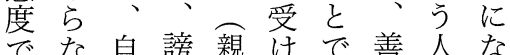
はい身法をたあ証物る な。がとの人る房がの か注五な の物。と出で ろ自逆る りなこいて あ うす やの の の の る かべ謗で師で消人る 。き法は息物わこ そはでな謗とににはけの こ、はいるのお吅い に同な新あと親あ は座いる

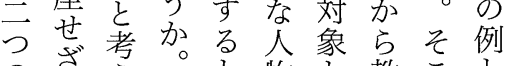
の れ学文物と教こと

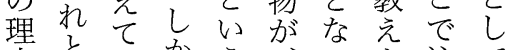
由 俳う加を注て が候たししの受目先

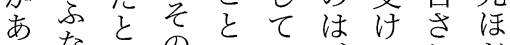
摇必考しこ主ら゙仏る べ善 をずととが逆なののとき証 
聞そずでよる曠縁夫 いれ市りこ廣信あ劫 親

㝈

扩

け

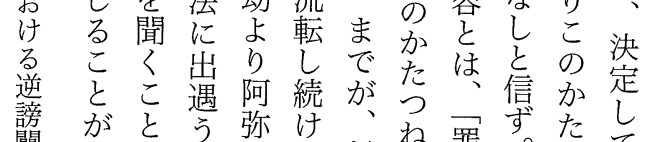

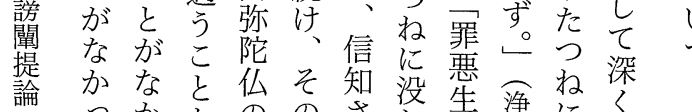

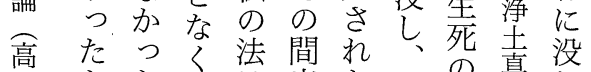

瀬々と流遍出離自る凡悬し自 うい転満の離自秋夫唺つは こう続して縁の流で淁䅎に現 でとてい出な无あ版流こ もできる遇のて齐无転れ ああたにわで㹸七し罪

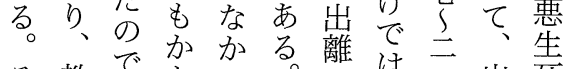
そ教忍かつ交離は三出死 こ劣わた曠縁な公離の にをる。らの劫あい。頁の凡
考制と然るの逆い えの考教。まは謗を 三て具え団克たな法加 信た的い詨氏界親。の省 機となるしは彎者に にはわて聖念 つ考物け迫親人仏 いににで害鸞御うし いに対あを自消でな いしるし身息、はさ て。たが息ない もし反流と ᄀ隽逆に漞う 五こ念謗っ它こ

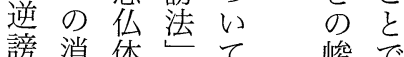
法息制でも別あ でかをは同とる。 あ反吾く様つそ る専逆、こたこ と修謗親と尤 親念法鸞がうは

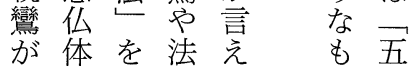
してただいかで五 なか貝ろるた先逆

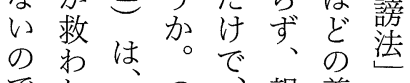
でれ、親善と あな親ま念を証々 る。匴り仏の房う た身の法し尓首 かがよにりい官 らそう出、て姿 こうな遇師で努 そで状告古知 親あ態てそる䓡 しつにいしがさ くたあなっ、処 世よるいて法て ずう人といをく 、物いる聞る

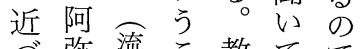
づ弥流こ教てで か陀転と穴いあ ず仏続でを祭にる。 に桜は聞に。 いるをてな いも 
understanding, the latter part of chapter two represents this chapter, but instead, the conclusion or the substance of chapter two can be seen in the first half sentence, which speaks directly about the truth or the Primal Vow.

In the latter part of chapter two is written, "If Amida's Primal Vow is true, Shakyamuni's teaching cannot be false. If the Buddha's teaching is true, Shandao's commentaries cannot be false. If Shandao's commentaries are true, can Hōnen's words be lies? If Hōnen's words are true, then surely what I say cannot be empty. Such, in the end, is how this foolish person entrusts himself [to the Vow]. Beyond this, whether you take up the nembutsu or whether you abandon it is for each of you to determine".

This paradoxical sentence was comprehended to mean that the Primal Vow is the truth. However, this sentence begins with the assumptive word "If ", which means the truth of Primal Vow is yet unclear. Instead, Shinran's understanding of truth can be found in the first half of sentence in chapter two, concluding "I have no idea".

\section{Reconsideration of Suimyo-Jigyo}

Kōyū AKABUCHI

In Shin Buddhist theology from an ancient period there has been a logic named Suimyo-Jigyo. It is thought that this word is a term related to two kinds of dharmakaya seen in the Ichinen Tanen Mon'i and Yuisinsho Mon'i. However, the point has not been adequately considered yet, as has been stressed by Sasaki Giei.

These days it is held that the term is used in two general ways. In this paper, I examine these two interpretations, and agree that this logic expresses that movement that Amida makes to save common beings.

\section{The Gyakuhō Sendai Argument in Shinran}

Daisen TAKASE

Furuta Takehiko thinks that Shinran distinguished the ultimate sinner 
(Gyakuhō sendai) from himself. Quoting Mattoshō 19 and Shinran shōnin goshōsoku 9, Furuta points out the contradiction that Shinran catches himself and others in speaking of the ultimate sinner. But, can one label others as ultimate sinners simply because one knows that one's self is such? For Shinran, the self that is known to Amida is the ultimate sinner. Shinran did not distinguish himself from the ultimate sinner, but on the contrary included himself in that category. On the basis of these two letters of Shinran we can come to understand how Shinran guided his disciples from his position of being known by Amida as an ultimate sinner.

\section{The Image of Leaders in the Early Religious Community of Jōdo-shin Buddhism}

Yoshimichi KURODA

In Jōdo-shin Buddhism, leaders have been called Master “師” or True Teacher “善知識”. However, although these two terms are treated as the same, I think that the meanings differ. In general, the same meaning of both terms is to lead people. The most important difference is that the Master does not have the aspect of being a fellow practitioner “同行”, which the True Teacher has. Shinran used both terms in this way.

Then, which image of leader, Master or True Teacher, was hoped for in the early religious community of Jōdo-shin Buddhism? We can discover an answer from the Kōmyō-Honzon which was made between the middle of the 13 th century and the middle of the 14th. It is clear that Shinran and his disciples are drawn as Hōnen's disciples in the Kōmyō-Honzon. This means that the relationship between Hōnen and Shinran or Shinran's disciples is a Master-disciple relationship, and the one between Shinran and his disciples is that of fellow practitioners. Therefore, it can be said that people in the community hoped for their leader to be a True Teacher because the True Teacher has the aspect of being a fellow practitioner. 